\title{
Article \\ Efficient Phosphorus Recovery from Municipal Wastewater Using Enhanced Biological Phosphorus Removal in an Anaerobic/Anoxic/Aerobic Membrane Bioreactor and Magnesium-Based Pellets
}

\author{
Elvis Eghombi ${ }^{1}$, Hyunsik Kim ${ }^{1}$, Yang-Hun Choi ${ }^{2}{ }^{(D}$, Mi-Hwa Baek ${ }^{3}$, Mallikarjuna N. Nadagouda ${ }^{4}$, \\ Pyung-Kyu Park ${ }^{5, *(D)}$ and Soryong Chae ${ }^{1, *(D)}$
}

1 Department of Chemical and Environmental Engineering, University of Cincinnati, 2901 Woodside Drive, Cincinnati, OH 45221, USA; eghombielvis@yahoo.com (E.E.); kim4hk@mail.uc.edu (H.K.)

2 Water Treatment Development Team, LOTTE Chemical Advanced Materials, 56 Gosan-ro, Uiwang-si 16073, Korea; yanghunchoi@lotte.net

3 Monomer R\&D Division, LOTTE Chemical R\&D Center, 115 Gajeongbuk-ro, Daejeon 34110, Korea; mihwabaek@lotte.net

4 Department of Mechanical and Materials Engineering, Wright State University, Dayton, OH 45435, USA nadagouda.mallikarjuna@epa.gov

check for

updates

Citation: Eghombi, E.; Kim, H.; Choi, Y.-H.; Baek, M.-H.; Nadagouda, M.N.; Park, P.-K.; Chae, S. Efficient Phosphorus Recovery from Municipal Wastewater Using Enhanced Biological Phosphorus Removal in an Anaerobic/Anoxic/ Aerobic Membrane Bioreactor and Magnesium-Based Pellets. Membranes 2022, 12, 210.

https://doi.org/10.3390/

membranes 12020210

Academic Editors: Miao Tian,

Yuqing Lin and Ralph Rolly

Gonzales

Received: 7 January 2022

Accepted: 7 February 2022

Published: 10 February 2022

Publisher's Note: MDPI stays neutral with regard to jurisdictional claims in published maps and institutional affiliations.

Copyright: (c) 2022 by the authors. Licensee MDPI, Basel, Switzerland. This article is an open access article distributed under the terms and conditions of the Creative Commons Attribution (CC BY) license (https:/ / creativecommons.org/licenses/by/ $4.0 /)$.
5 Department of Environmental and Energy Engineering, Yonsei University, 1 Yonseidae-gil, Wonju 26493, Korea

* Correspondence: pkpark@yonsei.ac.kr (P.-K.P.); chaesg@ucmail.uc.edu (S.C.); Tel.: +82-33-760-2890 (P.-K.P.); +1-513-556-4353 (S.C.)

\begin{abstract}
Municipal wastewater has been identified as a potential source of natural phosphorus $(\mathrm{P})$ that is projected to become depleted in a few decades based on current exploitation rates. This paper focuses on combining a bench-scale anaerobic/anoxic/aerobic membrane bioreactor (MBR) and magnesium carbonate $\left(\mathrm{MgCO}_{3}\right)$-based pellets to effectively recover $\mathrm{P}$ from municipal wastewater. Ethanol was introduced into the anoxic zone of the MBR system as an external carbon source to improve P release via the enhanced biological phosphorus removal (EBPR) mechanism, making it available for adsorption by the continuous-flow $\mathrm{MgCO}_{3}$ pellet column. An increase in the concentration of $\mathrm{P}$ in the MBR effluent led to an increase in the $\mathrm{P}$ adsorption capacity of the $\mathrm{MgCO}_{3}$ pellets. As a result, the anaerobic/anoxic/aerobic MBR system, combined with a $\mathrm{MgCO}_{3}$ pellet column and ethanol, achieved 91.6\% P recovery from municipal wastewater, resulting in a maximum $\mathrm{P}$ adsorption capacity of $12.8 \mathrm{mg}$ $\mathrm{P} / \mathrm{g} \mathrm{MgCO}_{3}$ through the continuous-flow $\mathrm{MgCO}_{3}$ pellet column. Although the introduction of ethanol into the anoxic zone was instrumental in releasing $\mathrm{P}$ through the EBPR, it could potentially increase membrane fouling by increasing the concentration of extracellular polymeric substances (EPSs) in the anoxic zone.
\end{abstract}

Keywords: phosphorus; municipal wastewater; anaerobic/anoxic/aerobic membrane bioreactor; enhanced biological phosphorus removal mechanism; ethanol; membrane fouling; extracellular polymeric substances

\section{Introduction}

Natural phosphorus $(\mathrm{P})$ reserves will be depleted in a few decades if the phosphorus fertilizer demand increases at 3\% per year [1]. Municipal wastewater has been identified as an alternative $P$ source that potentially reduces natural $P$ extraction from phosphate rocks [2]. It has been estimated that $15-20 \%$ of the world's phosphorus demand could be satisfied by its recovery from municipal wastewater $[1,3,4]$. A recent study showed that humans discharge about 3.7 Mt of P into wastewater, making its recovery from wastewater a desirable alternative capable of providing sustainable phosphorus supplies that could supplement natural phosphorus [4]. 
This essential element (i.e., P) in sewage can be recovered through chemical precipitation, biological processes, physical adsorption, sewage sludge, wetland plants, and wastewater irrigation. Chemical precipitation, physical adsorption, and biological removal using the enhanced biological phosphorus removal (EBPR) mechanism are the most widely used methods [5].

Struvite $\left(\mathrm{MgNH}_{4} \mathrm{PO}_{4} \cdot 6 \mathrm{H}_{2} \mathrm{O}\right)$, or calcium phosphate precipitation, is also regarded as one of the most promising phosphorus recovery processes since the resultant products can be directly applied in agriculture as a fertilizer or accepted readily by the phosphorus manufacturing industry $[1,6,7]$. However, this recovery method with chemicals requires wastewater with a high phosphorus concentration to be feasible, which is not the case with municipal wastewater that is naturally diluted with a phosphorus concentration of less than $10 \mathrm{mg} / \mathrm{L}$ [8].

Adsorptive materials such as modified iron oxide iron oxide, calcined waste eggshells, and magnesium-modified corn biochar have also been proven to effectively remove and recover phosphate from aqueous suspensions. However, a major setback with this technology is the "bottleneck" phenomenon where the adsorbent is no longer applicable after saturation [9-12]. Therefore, this necessitates fabricating an excellent adsorbent material with highly recyclable properties that can be used as an alternative in $\mathrm{P}$ recovery from wastewater.

Magnesium carbonate $\left(\mathrm{MgCO}_{3}\right)$-based materials, especially beads and pellets, are adsorptive materials that have exhibited excellent capabilities for effective and sustainable recovery of $\mathrm{P}$ from wastewater. The effectiveness of the pellets is attributed to $\mathrm{MgCO}_{3}$ 's chemical and physical stability in water and its environmentally friendly properties that guarantee its application in agriculture as a slow-release material [13,14].

The biological removal method using the EBPR mechanism is a relatively inexpensive and ecologically friendly process used in phosphorus recovery even though its stability and reliability are hard to attain [15]. Biological phosphorus removal via the EBPR process can accumulate up to $90 \%$ of $\mathrm{P}$ in sludge [16]. Ultimately, phosphorus removal is achieved by withdrawing excess sludge containing the accumulated poly-P from the engineered system [17].

The effectiveness of the EBPR process is determined by the type and amount of carbon sources available in the wastewater under treatment [18]. Among various carbon sources, ethanol is preferably used by most wastewater treatment plants (WWTPs) in the EBPR process because it is cheap and sustainable compared to other carbon sources [19].

Although the EBPR process is an environmentally sustainable method for phosphorus recovery from municipal wastewater, it has some limitations in that it is unstable and unreliable [15]. In addition, phosphorus removal is achieved by discharging the phosphorus-rich excess sludge with heavy metals and pathogens [20], resulting in additional disposal costs since the recovered phosphorus is not separated from the sludge [21].

Membrane bioreactors (MBRs) have been widely used in the treatment of municipal and industrial wastewater as membrane separation technology is increasingly becoming an innovation in biological wastewater treatment [22-24]. Because of the high quality (particle and bacteria free) of the resultant effluent from MBRs, the effluent can be directly discharged into the environment or used directly for non-potable applications such as irrigation and industrial applications.

Although MBRs are a stable, reliable, and sustainable wastewater treatment method that achieve excellent solid-liquid separation, they still cannot recover the phosphorus released in the liquid stream. Therefore, another technology that could be operated with an MBR to recover P from the liquid stream discharged is needed.

In our previous studies, granular adsorptive pellets were fabricated by combining $\mathrm{MgCO}_{3}$ with varying amounts of cellulose binder to remove phosphate from water. In a batch experiment, a maximum adsorption capacity of $96.4 \mathrm{mg}$ of $\mathrm{P}$ per gram of $\mathrm{MgCO}_{3}$ was achieved from a synthetic orthophosphate solution (initial P concentration $=160 \mathrm{mg} / \mathrm{L}$ ) for 25 days, following a pseudo-second-order kinetics model [14]. 
The following study was tested using real municipal wastewater in combination with MBR. The MBR effluent was directly fed to a continuous flow column packed with $\mathrm{MgCO}_{3}$ pellets at various flow rates (i.e., $10 \mathrm{~L} / \mathrm{d}$ to $2.5 \mathrm{~L} / \mathrm{d}$ ). Under the optimum conditions, $73.1 \%$ of phosphorus was recovered from the MBR effluent, but the phosphorus's adsorption capacity using $\mathrm{MgCO}_{3}$ pellets was limited to $0.47 \mathrm{mg}$ of phosphorus per gram of $\mathrm{MgCO}_{3}$ [25]. By switching the feed water from a synthetic solution to natural municipal wastewater, there was a dramatic change in the $\mathrm{P}$ adsorption capacity of $\mathrm{MgCO}_{3}$ from $96.4 \mathrm{mg}$ of $\mathrm{P}$ per gram of $\mathrm{MgCO}_{3}$ to $0.47 \mathrm{mg}$ of $\mathrm{P}$ per gram of $\mathrm{MgCO}_{3}$.

The low adsorption capacity obtained in the previous study using real municipal wastewater requires a follow-up study to improve the phosphorus recovery efficiency. Therefore, this study aimed to improve P release from an anaerobic/anoxic/aerobic MBR via the EBPR mechanism by adding an external carbon source (i.e., ethanol) to enhance the adsorption capacity of $\mathrm{P}$ using $\mathrm{MgCO}_{3}$ pellets.

The MBR technology can efficiently remove particles, heavy metals, and pathogens from a mixed liquor that traditional biological processes cannot usually achieve [26-29]. Then, the particle- and pathogen-free MBR effluent was introduced to a continuous flow column reactor packed with $\mathrm{MgCO}_{3}$ pellets to recover the phosphorus. The effects of ethanol injection on P recovery and membrane fouling were determined.

\section{Materials and Methods}

\subsection{Characterization of Municipal Wastewater}

Municipal wastewater used for this experiment was collected from the Muddy Creek WWTP (Cincinnati, OH, USA) after primary settling. The temperature and $\mathrm{pH}$ were measured using a bench-top pH meter (Thermo Scientific, Waltham, MA, USA).

Key wastewater parameters such as chemical oxygen demand (COD), total phosphorus (TP), orthophosphate, total Kjeldahl nitrogen (TKN), ammonia, nitrates, nitrites, total suspended solids (TSS), mixed liquor suspended solids (MLSS), volatile suspended solids (VSS), and fecal coliform were analyzed at least three times per week using an ultraviolet/visible (UV/Vis) spectrophotometer (DR6000, HACH, Loveland, CO, USA) according to standard methods [30].

The detection limits of the key water quality parameters were: COD $=1-60 \mathrm{mg} / \mathrm{L}$ (ultra-low range) and $20-1500 \mathrm{mg} / \mathrm{L}$ (high range), phosphorus $=0.15-4.50 \mathrm{mg} / \mathrm{L}$ as $\mathrm{PO}_{4}{ }^{3-}$, Total Kjeldahl nitrogen $(\mathrm{TKN})=0-16 \mathrm{mg} / \mathrm{L}$ as $\mathrm{N}, \mathrm{NH}_{3}-\mathrm{N}=0.02-2.50 \mathrm{mg} / \mathrm{L}$ (low range) and $0.4-50.0 \mathrm{mg} / \mathrm{L}$ (high range), $\mathrm{NO}_{3}-\mathrm{N}=0.23-13.50 \mathrm{mg} / \mathrm{L}$, and $\mathrm{NO}_{2}-\mathrm{N}=0.015-0.6 \mathrm{mg} / \mathrm{L}$.

The primary effluent from Muddy Creek WWTP had an average concentration of total COD and TP of $217 \mathrm{mg} / \mathrm{L}$ and $4.1 \mathrm{mg} / \mathrm{L}$, respectively. The characteristics of the primary effluent during the experimental period are shown in Table 1.

Table 1. Characteristics of raw municipal wastewater and primary effluent from the Muddy Creek treatment plant (Cincinnati, OH, USA) used in this study (June 2020-February 2021).

\begin{tabular}{ccc}
\hline Parameter & Raw Wastewater & Primary Effluent \\
\hline Number of samples & 98 & 98 \\
\hline Total suspended solids (TSS), $\mathrm{mg} / \mathrm{L}$ & $1015 \pm 385$ & $635 \pm 317$ \\
\hline Total chemical oxygen demand (TCOD), $\mathrm{mg} / \mathrm{L}$ & $261.2 \pm 125.3$ & $217 \pm 123.8$ \\
\hline Soluble chemical oxygen demand (SCOD), $\mathrm{mg} / \mathrm{L}$ & $61 \pm 45$ & $50 \pm 31$ \\
\hline
\end{tabular}


Table 1. Cont.

\begin{tabular}{ccc}
\hline Parameter & Raw Wastewater & Primary Effluent \\
\hline Total Kjeldahl nitrogen (TKN), mg/L & $19.2 \pm 17.8$ & $18.1 \pm 16.9$ \\
\hline $\mathrm{NH}_{3}-\mathrm{N}, \mathrm{mg} / \mathrm{L}$ & $17.1 \pm 8.2$ & $16.9 \pm 7.3$ \\
\hline Total phosphorus (TP), $\mathrm{mg} / \mathrm{L}$ & $5.6 \pm 3.3$ & $4.1 \pm 3.5$ \\
\hline Orthophosphate, $\mathrm{mg} / \mathrm{L}$ & $2.2 \pm 1.2$ & $2.1 \pm 1.2$ \\
\hline Fecal coliform, $\mathrm{CFU} / 100 \mathrm{~mL}$ & $17,690 \pm 7600$ & $10,500 \pm 5680$ \\
\hline
\end{tabular}

\subsection{Bench-Scale Anaerobic/Anoxic/Aerobic MBR System}

A bench-scale anaerobic/anoxic/aerobic MBR has three compartments: an anaerobic zone $(1.0 \mathrm{~L})$, an anoxic zone $(2.4 \mathrm{~L})$, and an aerobic zone $(8.0 \mathrm{~L})$, with a total MBR operating volume of $11.4 \mathrm{~L}$ (Figure 1). The MBR was inoculated with sludge from the Muddy Creek WWTP (Cincinnati, OH, USA). The primary effluent from the Muddy Creek WWTP and MLSS recycled from the aerobic zone were introduced to the top of the anaerobic zone (oxidation-reduction potential (ORP) $<-450 \mathrm{mV}$ ) of the MBR to deplete the dissolved oxygen (DO) in the MLSS and moved to the anoxic zone. Then, the MLSSs overflowed from the top of the anaerobic zone to the anoxic zone (ORP $=-300 \sim-150 \mathrm{mV}$ ) to the aerobic zone (ORP $>200 \mathrm{mV}$ ). Complete mixing in the anoxic zone was obtained using a low-speed mixer and an impeller. Under alternating anaerobic/anoxic and aerobic conditions, the MBR achieved the EBPR mechanism, biological nitrification, and denitrification. Ethanol introduced into the anoxic zone enhanced the EBPR mechanism and denitrification processes.

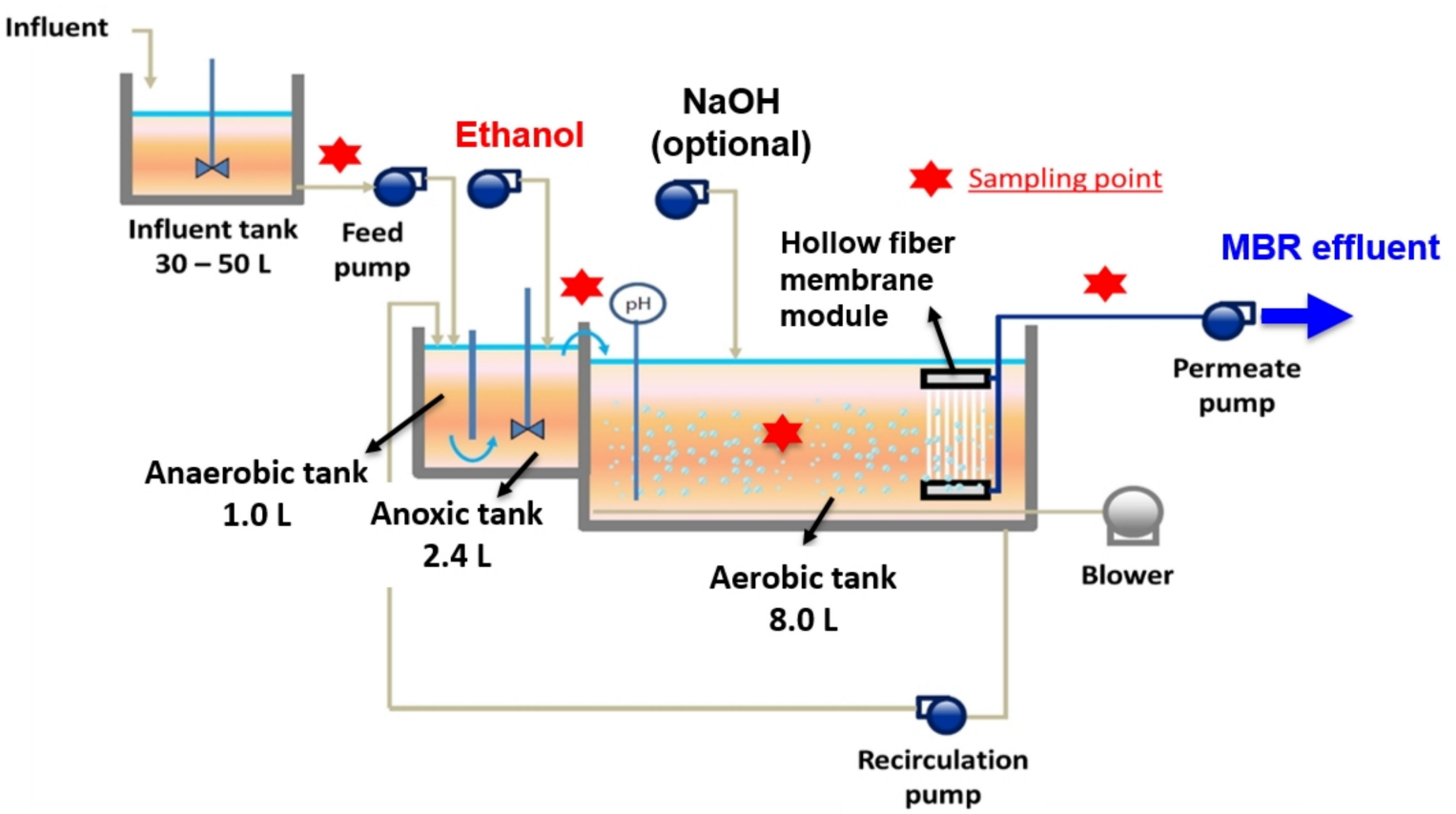

Figure 1. Schematic diagram of a bench-scale anaerobic/anoxic/aerobic MBR for simultaneous removal of organic matter, nitrogen, and phosphorus.

A hollow fiber polyvinylidene fluoride (PVDF) membrane module (with a nominal pore size of $0.03 \mu \mathrm{m}$; LOTTE Chemical, Daegu, Korea) was submerged in the aerobic zone (Phases 1-5) or the anoxic zone (Phases 6 and 7). Detailed information on the PVDF membrane can be found in our previous study [25].

A disk-type diffuser was installed in the aerobic zone at the bottom to provide air bubbles for the oxidation of organics and ammonia and to reduce membrane fouling. 
The DO concentration in the aerobic zone ranged between 3 and $5 \mathrm{mg} / \mathrm{L}$. In all the phases, the MBR effluent was withdrawn using a vacuum pump through the PVDF membrane module at $15 \mathrm{~L} / \mathrm{m}^{2} / \mathrm{h}(\mathrm{LMH})$. The MLSS were internally recycled back to the anaerobic zone at $300 \%$ of the feed flow rate from the aerobic tank.

The MBR was operated for various hydraulic retention times (HRTs) in seven different phases (Table 2). In Phases 1-3, the MBR was operated at an $16 \mathrm{~h}$ HRT (Phase 1), $12 \mathrm{~h}$ HRT (Phase 2), and $8 \mathrm{~h}$ (Phase 3) HRT by altering the feed flow rate without ethanol injection or a $\mathrm{MgCO}_{3}$ pellet column and lasted for 90 days. In Phase 4, the MBR was operated at an $8 \mathrm{~h}$ HRT with ethanol for 30 days $(100 \mathrm{mg} / \mathrm{L}$ as the COD ethanol solution was directly injected into the anoxic zone to increase the soluble $\mathrm{COD} / \mathrm{NH}_{3}-\mathrm{N}$ ratio of the influent from 2.5 to 7.5 in the anoxic zone for EBPR and biological denitrification).

Table 2. Operating conditions of the reactor (Phases 1-7).

\begin{tabular}{|c|c|c|c|c|c|c|c|}
\hline Phase & $\begin{array}{l}\text { HRT } \\
\text { (Hr) }\end{array}$ & $\begin{array}{c}\text { Internal } \\
\text { Recycle Rate }\end{array}$ & $\begin{array}{l}\text { Flux } \\
\text { (LMH) }\end{array}$ & Ethanol Injection & $\begin{array}{l}\text { Membrane } \\
\text { Location }\end{array}$ & P Recovery & $\begin{array}{l}\text { Period } \\
\text { (Days) }\end{array}$ \\
\hline 1 & 16 & \multirow{7}{*}{$\begin{array}{c}300 \% \text { of } \mathrm{Q} \\
\text { (feed flow rate) }\end{array}$} & 15 & \multirow{3}{*}{$\begin{array}{c}\text { Not applicable } \\
\left(\text { Soluble COD } / \mathrm{NH}_{3}-\mathrm{N}=2.5\right)\end{array}$} & Aerobic & No & 30 \\
\hline 2 & 12 & & 15 & & Aerobic & No & 30 \\
\hline 3 & 8 & & 15 & & Aerobic & No & 30 \\
\hline 4 & 8 & & 15 & \multirow{4}{*}{$\begin{array}{c}100 \mathrm{mg} / \mathrm{L} \text { as } \mathrm{COD} \\
\left(\text { Soluble COD/ } \mathrm{NH}_{3}-\mathrm{N}=7.5\right)\end{array}$} & Aerobic & No & 30 \\
\hline 5 & 8 & & 15 & & Aerobic & Using $\mathrm{MgCO}_{3}$ pellets & 30 \\
\hline 6 & 8 & & 7.5 & & Anoxic/Aerobic & Using $\mathrm{MgCO}_{3}$ pellets & 30 \\
\hline 7 & 8 & & 15 & & Anoxic & Using $\mathrm{MgCO}_{3}$ pellets & 15 \\
\hline
\end{tabular}

The $\mathrm{MgCO}_{3}$ pellet column was connected to the MBR system in Phases 5-7 and operated to recover $\mathrm{P}$ from the MBR effluent for an $8 \mathrm{~h}$ HRT for 30 days in each phase. The removal of particles and microorganisms was achieved by membrane filtration in the MBR, while the $\mathrm{MgCO}_{3}$ pellet column achieved further P recovery through physical adsorption. After every experimental phase, the membrane module was replaced with a new one. Phases 5 and 6 lasted 30 days each, while Phase 7 lasted only 15 days.

\subsection{A Continuous Flow Column Reactor with $\mathrm{MgCO}_{3}$ Pellets}

The $\mathrm{MgCO}_{3}$ pellet column designed for $\mathrm{P}$ recovery from the MBR effluent was introduced in Phases 5-7 (Table 2). The $\mathrm{MgCO}_{3}$ pellets used in this research experiment were loaded into a cylindrical column, having a length of $75 \mathrm{~cm}$ and a diameter of $3.5 \mathrm{~cm}$, with a total column volume of $0.72 \mathrm{~L}$. The column was packed with approximately $110 \mathrm{~g}$ of $\mathrm{MgCO}_{3}$ pellets. The $\mathrm{MgCO}_{3}$ pellets were lined at the top and bottom with $80 \mathrm{~g}$ of gravel to remove any solid particles that might have made their way into the column. The entire packing density of the column was $153.1 \mathrm{~g} / \mathrm{L}$ and was operated at room temperature $\left(20-25^{\circ} \mathrm{C}\right)$.

In Phase 5 (i.e., $100 \%$ of the MBR effluent was withdrawn from the PVDF membrane submerged in the aerobic zone), we introduced the $\mathrm{MBR}$ effluent into the $\mathrm{MgCO}_{3}$ pellet column for P recovery. In Phase 6, 50\% of the MBR effluent was withdrawn from the PVDF membrane submerged in the anoxic reactor for $\mathrm{P}$ recovery using the $\mathrm{MgCO}_{3}$ pellet column. The other $50 \%$ was withdrawn from the PVDF membrane submerged in the aerobic zone but discarded without P recovery. In Phase 7, 100\% of the MBR effluent was withdrawn from the PVDF membrane submerged in the anoxic reactor and then passed through the $\mathrm{MgCO}_{3}$ pellet column. The amount of $P$ recovered and the removal efficiency of $\mathrm{P}$ by the $\mathrm{MgCO}_{3}$ pellet column were determined using Equations (1) and (2), respectively:

$$
\text { Adsorption capacity }\left(\mathrm{mg} \mathrm{P} / \mathrm{g} \mathrm{MgCO}_{3} \text {-based pellets }\right)=\frac{\sum\left(\mathrm{C}_{\text {in }}-\mathrm{C}_{\text {out }}\right) \mathcal{Q}}{\mathcal{W}}
$$


where $C_{\text {in }}$ and $C_{\text {out }}$ are the daily average concentration $(\mathrm{mg} / \mathrm{L})$ of $\mathrm{P}$ in the influent and effluent water in the column, respectively. $\mathcal{W}$ is the weight $(\mathrm{g})$ of the $\mathrm{MgCO}_{3}$ pellets, and $\mathcal{Q}$ is the flow rate in the column $(\mathrm{L} / \mathrm{d})$.

$$
\text { Removal efficiency }=\left[\left(C_{\text {in }}-C_{\text {out }} / C_{\text {in }}\right)\right] \times 100
$$

where $C_{\text {in }}$ and $C_{\text {out }}$ are the daily average concentration of various constituents in the influent and effluent $(\mathrm{mg} / \mathrm{L})$, respectively.

\subsection{Characterization of Membrane Biofouling}

The samples were collected on the surfaces of fouled membranes (submerged either in the anoxic or aerobic zones), and extracellular polymeric substances (EPSs) were determined using the colorimetric analysis method based on their applicability to characterize membrane biofouling. Two major EPS fractions of interest (i.e., protein and carbohydrate EPSs) were determined using the modified Lowry method [31] and the phenol sulfuric acid method [32], respectively.

The applied methods were investigated in terms of their sensitivity to the selected standard compounds. The standard for proteins and polysaccharides was analyzed for their interference in all the applied colorimetric methods. The EPSs were dissolved in $0.02 \mathrm{M}$ sodium hydroxide and analyzed at $200 \mathrm{mg} / \mathrm{L}$ and $100 \mathrm{mg} / \mathrm{L}$ concentrations. The standard lines were prepared in a concentration range from 5 to $100 \mathrm{mg} / \mathrm{L}$. The absorbance of the EPS samples was then compared to that of the prepared standards. Cross-interference of the standard compounds was tested at $50 \mathrm{mg} / \mathrm{L}, 100 \mathrm{mg} / \mathrm{L}$, and $1000 \mathrm{mg} / \mathrm{L}$ [33].

\section{Results and Discussion}

\subsection{Performance of the Anaerobic/Anoxic/Aerobic MBR System}

The MBR system was operated in seven different phases according to the operations and design conditions listed in Table 2. Phases 1-3 were operated without an external carbon source, which was later introduced into the system during Phase 4 and used throughout the remaining three phases. Although the HRT decreased from $16 \mathrm{~h}$ (Phase 1) to $8 \mathrm{~h}$ (Phase 3), the COD concentration in the MBR effluent ranged between 2.5 and $4.5 \mathrm{mg} / \mathrm{L}$ ( $>97 \%$ removal). The concentrations of total nitrogen (TN) and TP ranged between 13.8 and $19.9 \mathrm{mg} / \mathrm{L}$ and between 1.7 and $3.7 \mathrm{mg} / \mathrm{L}$, respectively. The MBR achieved a $>99.9 \%$ removal efficiency for both TSS and fecal coliforms (5 log removal) in these phases (Table 3).

Table 3. Water quality of the MBR effluent (Phases 1-4).

\begin{tabular}{ccccc}
\hline Condition/Parameter & Phase $\mathbf{1}$ & Phase $\mathbf{2}$ & Phase 3 & Phase 4 \\
\hline HRT & 16 & 12 & 8 & 8 \\
\hline External carbon (ethanol) as COD $(\mathrm{mg} / \mathrm{L})$ & 0 & 0 & 0 & 100 \\
\hline Number of measurements & 12 & 12 & 12 & 12 \\
\hline TSS $(\mathrm{mg} / \mathrm{L})$ & $\mathrm{ND}$ & $\mathrm{ND}$ & $\mathrm{ND}$ & $\mathrm{ND}$ \\
\hline $\mathrm{TCOD}(\mathrm{mg} / \mathrm{L})$ & $2.5 \pm 0.8$ & $3.9 \pm 0.5$ & $4.5 \pm 1.0$ & $5.2 \pm 2.6$ \\
\hline $\mathrm{TN}(\mathrm{mg} / \mathrm{L})=\mathrm{TKN}+\mathrm{NO}-\mathrm{N}$ & $13.8 \pm 0.2$ & $18.4 \pm 0.5$ & $19.9 \pm 0.5$ & $3.5 \pm 0.4$ \\
\hline $\mathrm{TP}(\mathrm{mg} / \mathrm{L})$ & $1.7 \pm 0.3$ & $3.3 \pm 0.3$ & $3.7 \pm 0.3$ & $2.0 \pm 0.3$ \\
\hline Fecal coliform $(\mathrm{CFU} / 100 \mathrm{~mL})$ & $\mathrm{ND}$ & $\mathrm{ND}$ & $\mathrm{ND}$ & $\mathrm{ND}$ \\
\hline
\end{tabular}

ND: not detected, CFU: colony-forming unit.

The high removal efficiencies for nutrients (i.e., TN and TP) achieved in Phase 4, as compared to the other three phases, was because the ethanol injection improved denitrification efficiency by serving as a substrate supplement for heterotrophic and facultative bacteria present in the system. Ethanol also improved the EBPR mechanism by encouraging the growth of PAOs, which have an unusual ability to release and uptake $\mathrm{P}$ from the 
system [18]. The high removal efficiencies in Phase 4 led to a better effluent quality than that in the first three phases (Table 4).

Table 4. Overall performance of the MBR system (Phases 1-4).

\begin{tabular}{ccccc}
\hline Parameter & Phase 1 & Phase 2 & Phase 3 & Phase 4 \\
\hline Number of measurements & 12 & 12 & 12 & 12 \\
\hline TSS (Re. \%) & $>99.9$ & $>99.9$ & $>99.9$ & $>99.9$ \\
\hline TCOD (Re. \%) & 97.4 & 98.1 & 98.2 & 97.7 \\
\hline TN $($ Re. $\%)=$ TKN $+\mathrm{NO}_{3}-\mathrm{N}$ & 20.7 & 26.1 & 29.2 & 80.1 \\
\hline TP $($ Re. $\%)$ & 5.6 & 5.7 & 7.5 & 25.9 \\
\hline Fecal coliform (Re. \%) & $>99.999$ & $>99.999$ & $>99.999$ & $>99.999$ \\
\hline
\end{tabular}

After introducing ethanol into the anoxic MBR zone as an external carbon source, the MBR effluent was introduced to a continuous flow column packed with $\mathrm{MgCO}_{3}$ pellets designed for P adsorption in Phases 5-7. In Phase 5, 100\% of the water flux extracted from the aerobic reactor was introduced into the $\mathrm{MgCO}_{3}$ column at a flow rate of $15 \mathrm{LMH}$ for 30 days.

The COD and $\mathrm{TN}$ concentrations in the $\mathrm{MgCO}_{3}$ column effluent were marinated at $3.0 \mathrm{mg} / \mathrm{L}$. The TP concentration was also reduced from $1.6 \mathrm{mg} / \mathrm{L}$ in the MBR effluent to $0.4 \mathrm{mg} / \mathrm{L}$ in the $\mathrm{MgCO}_{3}$ column effluent, improving the TP removal efficiency significantly, from $38.5 \%$ when using the $\mathrm{MBR}$ to $84.6 \%$ when using the entire system (i.e., $\mathrm{MBR}+\mathrm{MgCO}_{3}$ column). Both the $\mathrm{MBR}$ and $\mathrm{MgCO}_{3}$ pellet column showed similar removal efficiencies of $>99.9 \%$ for TSS and fecal coliforms. The higher removal efficiencies were observed for $\mathrm{COD}, \mathrm{TN}$, and TP due to the further removal of organic matter, ammonia, and $\mathrm{P}$ by the $\mathrm{MgCO}_{3}$ pellet column during $\mathrm{P}$ adsorption (Table 5).

Table 5. Performance of the MBR system and $\mathrm{MgCO}_{3}$ column in Phase 5.

\begin{tabular}{|c|c|c|c|c|c|}
\hline \multirow{2}{*}{ Parameter } & \multicolumn{3}{|c|}{ MBR Effluent } & \multicolumn{2}{|c|}{$\mathrm{MBR}+\mathrm{MgCO}_{3}$ Effluent } \\
\hline & In & Out & $\operatorname{Re}(\%)$ & Out & $\operatorname{Re}(\%)$ \\
\hline TSS (mg/L) & 585 & ND & $>99.9$ & ND & $>99.9$ \\
\hline TCOD $(\mathrm{mg} / \mathrm{L})$ & 137.0 & 3.4 & \multirow{2}{*}{97.5} & 3.0 & \multirow{2}{*}{97.8} \\
\hline Soluble COD (mg/L) & 51.8 & - & & - & \\
\hline $\mathrm{NH}_{3}-\mathrm{N}(\mathrm{mg} / \mathrm{L})$ & 13.7 & 0.1 & 99.2 & ND & $>99.9$ \\
\hline $\mathrm{NO}_{2}-\mathrm{N}$ and $\mathrm{NO}_{3}-\mathrm{N}(\mathrm{mg} / \mathrm{L})$ & 0.2 & 3.3 & - & 3.3 & - \\
\hline $\mathrm{TN}\left(\mathrm{NH}_{3}-\mathrm{N}+\mathrm{NO}_{2}-\mathrm{N}+\mathrm{NO}_{3}-\mathrm{N}\right)$ & 13.9 & 3.4 & 75.5 & 3.3 & 76.3 \\
\hline $\mathrm{TP}(\mathrm{mg} / \mathrm{L})$ & 2.6 & 1.6 & \multirow{2}{*}{38.5} & 0.4 & \multirow{2}{*}{84.6} \\
\hline Orthophosphate (mg/L) & 1.7 & 1.6 & & 0.4 & \\
\hline Fecal coliform (CFU/100 mL) & 2100 & ND & $>99.999$ & ND & $>99.999$ \\
\hline
\end{tabular}

However, in Phase 6, only 50\% of the water flux (i.e., 7.5 LMH) was withdrawn from the membrane submerged in the anoxic MBR zone, then introduced to the $\mathrm{MgCO}_{3}$ column for $\mathrm{P}$ recovery. The other $50 \%$ was withdrawn from the aerobic MBR zone and discarded without $\mathrm{P}$ recovery. As shown in Table 6, the COD concentration in the aerobic MBR effluent was $4.2 \mathrm{mg} / \mathrm{L}$ with a removal efficiency of $96.6 \%$. A higher COD concentration of $7.6 \mathrm{mg} / \mathrm{L}$ was observed in the anoxic $\mathrm{MBR}$ effluent and the $\mathrm{MgCO}_{3}$ system's effluent with a reduced removal efficiency of $93.8 \%$ compared to what was observed in the aerobic MBR effluent. The low COD concentration in the anoxic MBR effluent and $\mathrm{MgCO}_{3}$ system's effluent compared to that in the aerobic MBR effluent can be attributed to withdrawal from the anoxic MBR zone where some organic matter was still unoxidized by microorganisms. 
Table 6. Performance of the MBR system and $\mathrm{MgCO}_{3}$ column in Phase 6.

\begin{tabular}{|c|c|c|c|c|c|c|}
\hline \multirow[t]{2}{*}{ Parameter } & \multicolumn{3}{|c|}{$\begin{array}{l}\text { MBR Effluent from the } \\
\text { Aerobic Zone ( } 50 \% \text { of } Q \text { ) }\end{array}$} & \multicolumn{3}{|c|}{$\begin{array}{l}\text { MBR Effluent from Anoxic Zone } \\
(50 \% \text { of } Q)+\mathrm{MgCO}_{3} \text { Effluent }\end{array}$} \\
\hline & In & Out & $\operatorname{Re}(\%)$ & In & Out & $\operatorname{Re}(\%)$ \\
\hline TSS (mg/L) & 440 & ND & $>99.9$ & 440 & ND & $>99.9$ \\
\hline TCOD (mg/L) & 122.2 & 4.2 & \multirow{2}{*}{96.6} & 122.2 & 7.6 & \multirow{2}{*}{93.8} \\
\hline Soluble COD (mg/L) & 38.6 & - & & 38.6 & - & \\
\hline $\mathrm{NH}_{3}-\mathrm{N}(\mathrm{mg} / \mathrm{L})$ & 8.5 & 0.1 & 98.8 & 8.5 & 0.1 & 98.8 \\
\hline $\mathrm{NO}_{2}-\mathrm{N}$ and $\mathrm{NO}_{3}-\mathrm{N}(\mathrm{mg} / \mathrm{L})$ & 1.1 & 3.0 & - & 1.1 & 0.3 & - \\
\hline $\mathrm{TN}(\mathrm{mg} / \mathrm{L})$ & 9.6 & 3.1 & 67.7 & 9.6 & 0.4 & 95.8 \\
\hline $\mathrm{TP}$ (mg/L) & 1.7 & 1.2 & \multirow{2}{*}{29.4} & 1.7 & 0.6 & \multirow{2}{*}{64.7} \\
\hline Orthophosphate (mg/L) & 1.1 & 1.2 & & 1.1 & 0.6 & \\
\hline
\end{tabular}

ND: not detected.

The concentration of TP in the aerobic MBR effluent was $1.2 \mathrm{mg} / \mathrm{L}$ with a removal efficiency of $29.4 \%$. In the anoxic MBR effluent and $\mathrm{MgCO}_{3}$ effluent, the TP concentration dropped to $0.6 \mathrm{mg} / \mathrm{L}$ with a removal efficiency of $64.7 \%$. The high TP removal efficiency observed by the $\mathrm{MgCO}_{3}$ pellets in this phase can be attributed to the EPBR mechanism in the anoxic MBR zone (where withdrawal took place) that released $\mathrm{P}$ and made it available for adsorption by the $\mathrm{MgCO}_{3}$ pellet column.

A high TN concentration of $3.1 \mathrm{mg} / \mathrm{L}$ and a low removal efficiency of $67.7 \%$ were observed in the aerobic MBR effluent because of nitrification in this reactor where oxygen was present. On the contrary, a low TN concentration of $0.4 \mathrm{mg} / \mathrm{L}$ and a high removal efficiency of $95.8 \%$ were observed in the anoxic MBR effluent and $\mathrm{MgCO}_{3}$ effluent due to direct withdrawal from the anoxic MBR zone where denitrification was taking place because of the absence of oxygen.

This high performance by the anoxic $\mathrm{MBR}$ and $\mathrm{MgCO}_{3}$ effluent system in terms of TN removal was also due to further removal of ammonia by the $\mathrm{MgCO}_{3}$ pellet column (Table 6). As reported in our previous study, the presence of phosphate and ammonia in an equal molar ratio and the $\mathrm{MgCO}_{3}$ pellets could lead to the formation of struvite (i.e., $\mathrm{Mg}^{2+}+$ $\left.\mathrm{NH}_{4}{ }^{+}+\mathrm{PO}_{4}{ }^{3-}+6 \mathrm{H}_{2} \mathrm{O} \rightarrow \mathrm{NH}_{4} \mathrm{MgPO}_{4} \cdot 6 \mathrm{H}_{2} \mathrm{O}\right)$, resulting in the removal of ammonia from the MBR effluent [25].

Phase 7 was the last phase of the experiment. During this phase, $100 \%$ of the water flux was withdrawn from the anoxic MBR zone, then introduced into the $\mathrm{MgCO}_{3}$ column for $P$ recovery. This lasted only 15 days due to operational challenges caused by high rates of membrane fouling (this will be discussed in Section 3.3 below).

As shown in Table 7, the COD concentrations in the anoxic MBR effluent and $\mathrm{MgCO}_{3}$ effluent were maintained at $8.5 \mathrm{mg} / \mathrm{L}(90.9 \%$ removal) and $7.7 \mathrm{mg} / \mathrm{L}(91.8 \%$ removal), respectively. The TN concentration was $4.3 \mathrm{mg} / \mathrm{L}$ in the anoxic MBR effluent and $2.6 \mathrm{mg} / \mathrm{L}$ in the $\mathrm{MgCO}_{3}$ effluent, achieving a removal efficiency of $51.7 \%$ and $70.8 \%$, respectively.

The highest TP removal (91.6\%) throughout the entire experimental operation was achieved in Phase 7. The comparatively (compared to Phases 1-6) high TP recovered in this phase can be attributed to high concentrations of soluble phosphorus in the MBR effluent that was released via the enhanced EBPR mechanism by ethanol (Figure 2). 
Table 7. Performance of the MBR system and $\mathrm{MgCO}_{3}$ column in Phase 7.

\begin{tabular}{|c|c|c|c|c|c|c|}
\hline \multirow{2}{*}{ Parameter } & \multicolumn{3}{|c|}{ MBR Effluent from the Anoxic Zone } & \multicolumn{3}{|c|}{$\begin{array}{c}\mathrm{MBR}+\mathrm{MgCO}_{3} \\
\text { Effluent }\end{array}$} \\
\hline & In & Out & $\operatorname{Re}(\%)$ & In & Out & $\operatorname{Re}(\%)$ \\
\hline TSS (mg/L) & 530 & ND & $>99.9$ & ND & ND & $>99.9$ \\
\hline TCOD (mg/L) & 93.6 & 8.5 & \multirow{2}{*}{90.9} & \multirow{2}{*}{8.5} & 7.7 & \multirow{2}{*}{91.8} \\
\hline Soluble COD (mg/L) & 43.2 & - & & & - & \\
\hline $\mathrm{NH}_{3}-\mathrm{N}(\mathrm{mg} / \mathrm{L})$ & 7.9 & 1.9 & 75.9 & 1.9 & 0.4 & 94.9 \\
\hline $\mathrm{NO}_{2}-\mathrm{N}$ and $\mathrm{NO}_{3}-\mathrm{N}(\mathrm{mg} / \mathrm{L})$ & 1.0 & 2.4 & - & 2.4 & 2.2 & - \\
\hline $\mathrm{TN}(\mathrm{mg} / \mathrm{L})$ & 8.9 & 4.3 & 51.7 & 4.3 & 2.6 & 70.8 \\
\hline $\mathrm{TP}(\mathrm{mg} / \mathrm{L})$ & 2.4 & 3.2 & \multirow{2}{*}{-} & \multirow{2}{*}{3.2} & 0.2 & \multirow{2}{*}{91.6} \\
\hline Orthophosphate (mg/L) & 1.0 & 3.2 & & & 0.2 & \\
\hline Fecal coliform (CFU /100 mL) & 2800 & ND & $>99.999$ & ND & ND & $>99.999$ \\
\hline
\end{tabular}

ND: not detected, CFU: colony-forming unit.

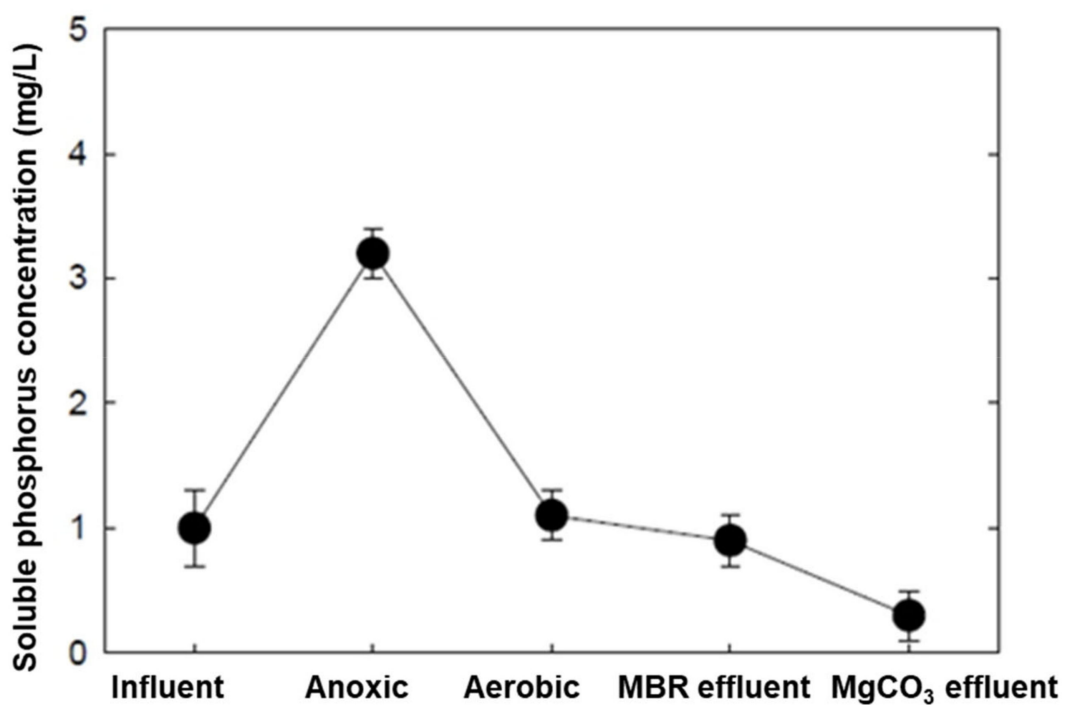

Figure 2. The enhanced EBPR mechanism was introduced in the MBR system by adding ethanol as an external carbon source (Phase 7).

In this phase, high removal efficiencies were observed for COD, TN, and TP due to the further removal of organic matter, $\mathrm{N}$, and $\mathrm{P}$ by the $\mathrm{MgCO}_{3}$ pellet column. Over $99.9 \%$ removal was achieved for TSS and fecal coliforms by both the MBR and the $\mathrm{MgCO}_{3}$ systems (Table 7). Based on the results obtained, it can be inferred that the high $\mathrm{P}$ concentration in the MBR effluent increased the adsorption capacity of the $\mathrm{MgCO}_{3}$.

Compared to Phases 1-4, Phases 5-7 achieved relatively high removal efficiencies for TSS, COD, TN, and TP compared to those in the previous phases. The overall best system performance was observed in Phase 5 with an overall removal efficiency of $>99.99 \%$ for TSS, $97.8 \%$ for COD, $76.3 \%$ for TN, and $84.6 \%$ for TP (Figure 3). Based on these results, it can be concluded that Phase 5 is the most favorable design and operating condition (i.e., $100 \%$ of the water flux extracted from the aerobic reactor was introduced into the $\mathrm{MgCO}_{3}$ column) for the effective removal of TSS, organic matter, and nutrients. 


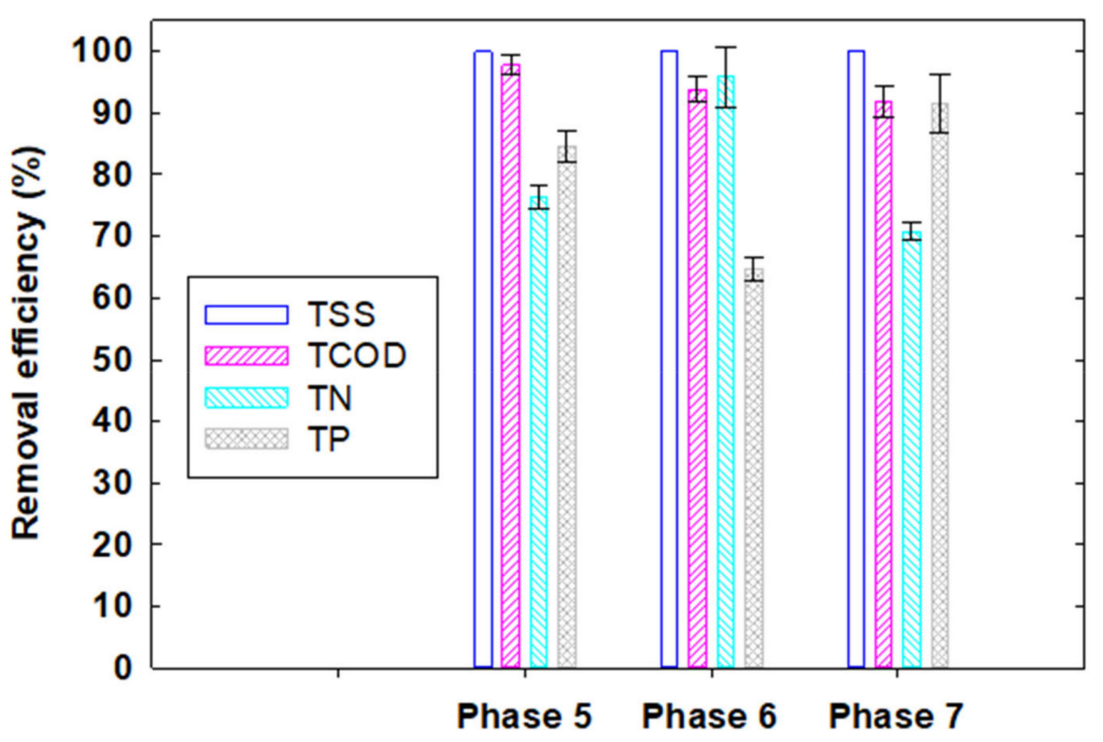

Figure 3. Removal efficiencies of TSS, TCOD, TN, and TP in Phases 5-7 by the aerobic MBR and $\mathrm{MgCO}_{3}$ column system.

\subsection{Effective Recovery of Phosphorus from the MBR Effluent}

$P$ recovery was achieved via the adsorption mechanism of the $\mathrm{MgCO}_{3}$ pellet column designed for this purpose. The capability of the column to recover $\mathrm{P}$ was studied in Phases 5-7 of the experiment under various operating conditions, as stated in Table 1. The $\mathrm{P}$ recovery capacity of the $\mathrm{MgCO}_{3}$-based pellets was determined using Equation (1) and is summarized in Table 8.

Table 8. Recovery of phosphorus using $\mathrm{MgCO}_{3}$ pellets from the MBR system.

\begin{tabular}{cccc}
\hline Phase & $\begin{array}{c}\text { Water Flux through the } \\
\text { PVDF Membrane (LMH) }\end{array}$ & $\begin{array}{c}\text { Operation Period } \\
\text { (Day) }\end{array}$ & $\begin{array}{c}\text { Adsorption Capacity } \\
\text { (mg P/g MgCO } \mathbf{3})\end{array}$ \\
\hline 5 & 15 & 30 & 10.2 \\
\hline 6 & 7.5 & 30 & 2.6 \\
\hline 7 & 15 & 15 & 12.8 \\
\hline
\end{tabular}

It was observed that the $\mathrm{P}$ concentration in the MBR effluent influenced the adsorption capacity of the $\mathrm{MgCO}_{3}$ pellets. In other words, the adsorption capacity of the pellets had a positive correlation with the P concentration in the column's influent.

The higher the $\mathrm{P}$ concentration in the column's influent, the higher the adsorption capacity of the pellets. This could explain why the highest $\mathrm{P}$ adsorption of $12.8 \mathrm{mg} \mathrm{P} / \mathrm{g}$ $\mathrm{MgCO}_{3}$ recorded by the column was observed in Phase 7 (i.e., 100\% water from the anoxic zone in the MBR). A somewhat high adsorption capacity of $10.2 \mathrm{mg} \mathrm{P} / \mathrm{g} \mathrm{MgCO}_{3}$ was also observed in Phase 5 (i.e., 100\% water from the aerobic MBR zone), and a very low adsorption capacity of $2.6 \mathrm{mg} \mathrm{P} / \mathrm{g} \mathrm{MgCO}_{3}$ was observed in Phase 6 due to reduced water flux and a low P concentration in the MBR effluent compared to Phase 7 (Tables 6 and 7).

\subsection{Characteristics of Membrane Fouling under Different Redox Conditions}

The impact of microorganisms on membrane biofouling in MBRs is inevitable [34-36]. As demonstrated by the transmembrane pressure (TMP), the membrane fouling rate began to rise at a slow pace, between a TMP of 0.14 and $0.19 \mathrm{kPa} /$ day in Phases 1-3 (Figure 4). The moderate rate of increase over time was due to the low concentrations of EPS ( $<5 \mathrm{mg}$ per membrane surface area, $\mathrm{cm}^{2}$ ) on the membrane surfaces in the MBR during the operating periods (data not shown). However, the dynamics changed in Phases 4-7 as an external carbon source (i.e., ethanol) was introduced into the MBR system. At this point, the rate of increase 
of TMP rose to about $0.45 \mathrm{kPa} /$ day for Phases 4 and 5 (Figure 5). This rapid increase can be attributed to a rise in biomass concentration in the reactor, as ethanol encouraged the growth of microorganisms in the MBR. As the biomass population continued to increase with time, they secreted high concentrations of EPS into the MBR system, which caused an increase in fluid viscosity and membrane resistance, consequently leading to an increase in TMP and membrane fouling (Figures 6 and 7).

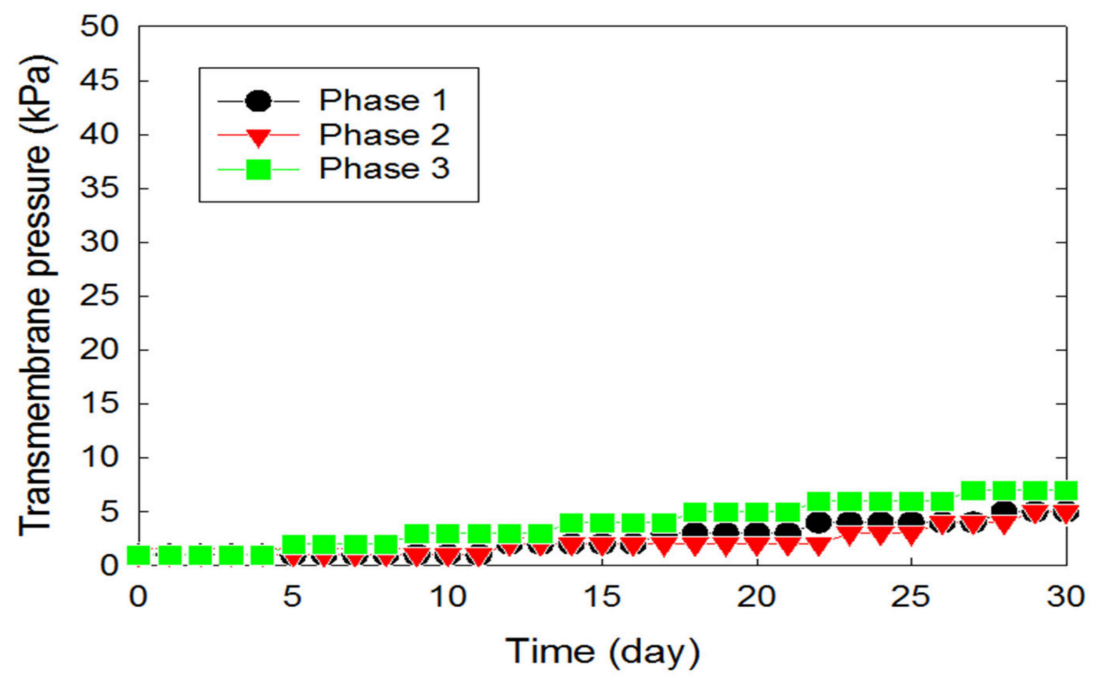

Figure 4. Increase in transmembrane pressure of the PVDF membrane submerged in the aerobic MBR zone as a function of time in Phase $1(\mathrm{HRT}=16 \mathrm{~h})$, Phase $2(\mathrm{HRT}=12 \mathrm{~h})$, and Phase $3(\mathrm{HRT}=8 \mathrm{~h})$ without ethanol.

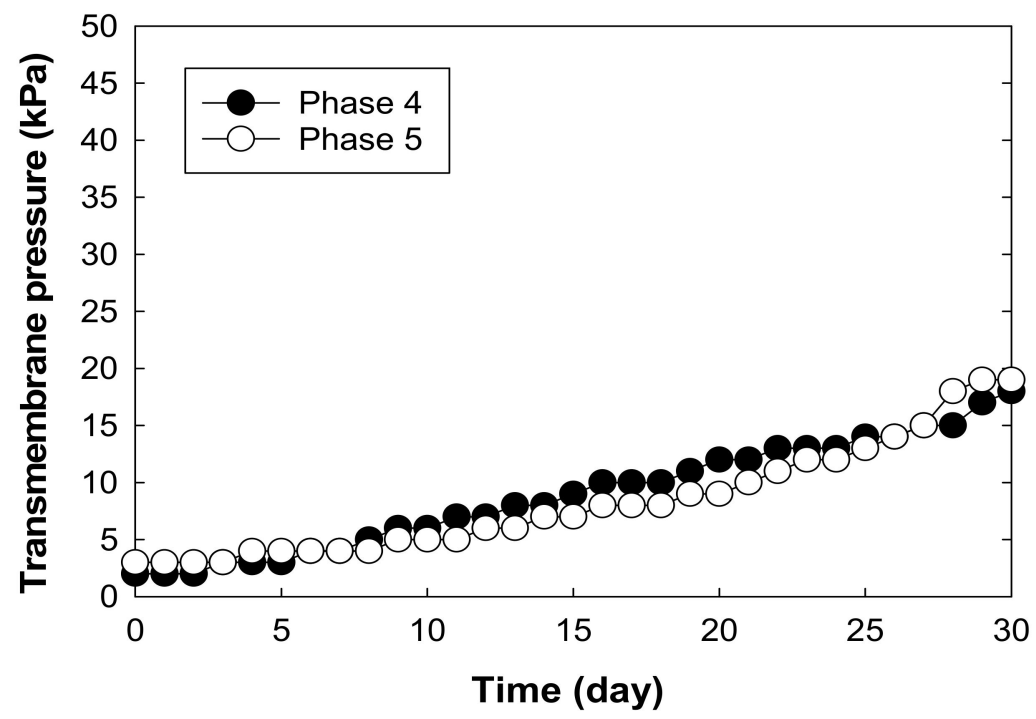

Figure 5. Increase in transmembrane pressure of the PVDF membrane submerged in the aerobic MBR zone as a function of time after the introduction of ethanol for an 8-h HRT in Phases 4 and 5.

The behavior of membrane fouling was different in Phases 6-7 because of a difference in the oxidation-reduction conditions under which the PVDF membrane was immersed. In the anoxic zone (Phase 6), the rate of TMP increase was about three times higher than what was observed in the aerobic MBR zone (Figure 6). 


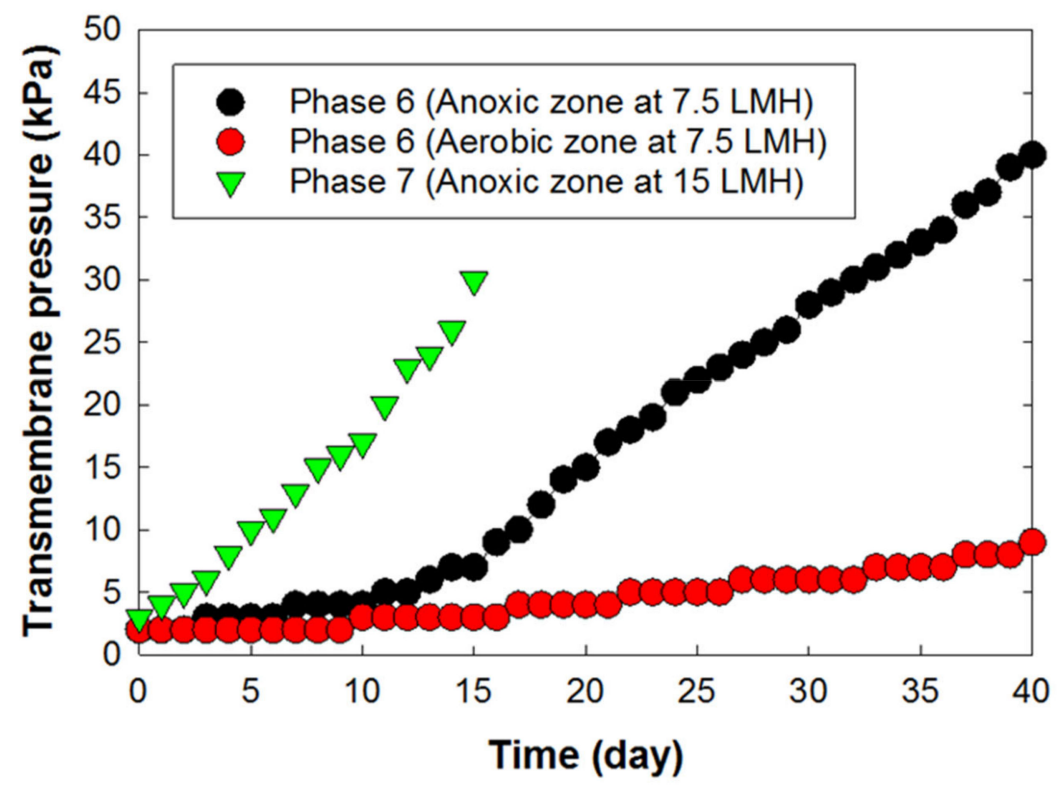

Figure 6. Increase in transmembrane pressure of the PVDF membrane submerged in the anoxic zones of the MBR as a function of time after introducing ethanol carbon source for an 8-h HRT in Phases 6 and 7.

In Phase 7, the rate of membrane fouling was alarming. The TMP's rate of increase rose to about $1.8 \mathrm{kPa} /$ day, and the operation lasted only 15 days. This increase in the membrane fouling rate in the anoxic zone was mainly due to the lack of the sufficient shear stress that can keep particles away from the membrane surface.

In addition, high concentrations of protein and carbohydrate EPS secreted by the biomass growth could be stimulated by ethanol and adversely affected membrane filterability (Figure 7). The introduction of the external carbon source may have led to an increase in EPS concentration, which increased the rate of membrane biofouling.

The average concentrations of carbohydrate and protein EPS fractions on the PVDF membrane were $18 \mathrm{mg}$ (Phase 5)-62 $\mathrm{mg}$ (Phase 7) per membrane surface area $\left(\mathrm{cm}^{2}\right)$ and $26 \mathrm{mg}$ (Phase 5)-84 mg (Phase 7) per membrane surface area $\left(\mathrm{cm}^{2}\right)$, respectively (Figure 7).

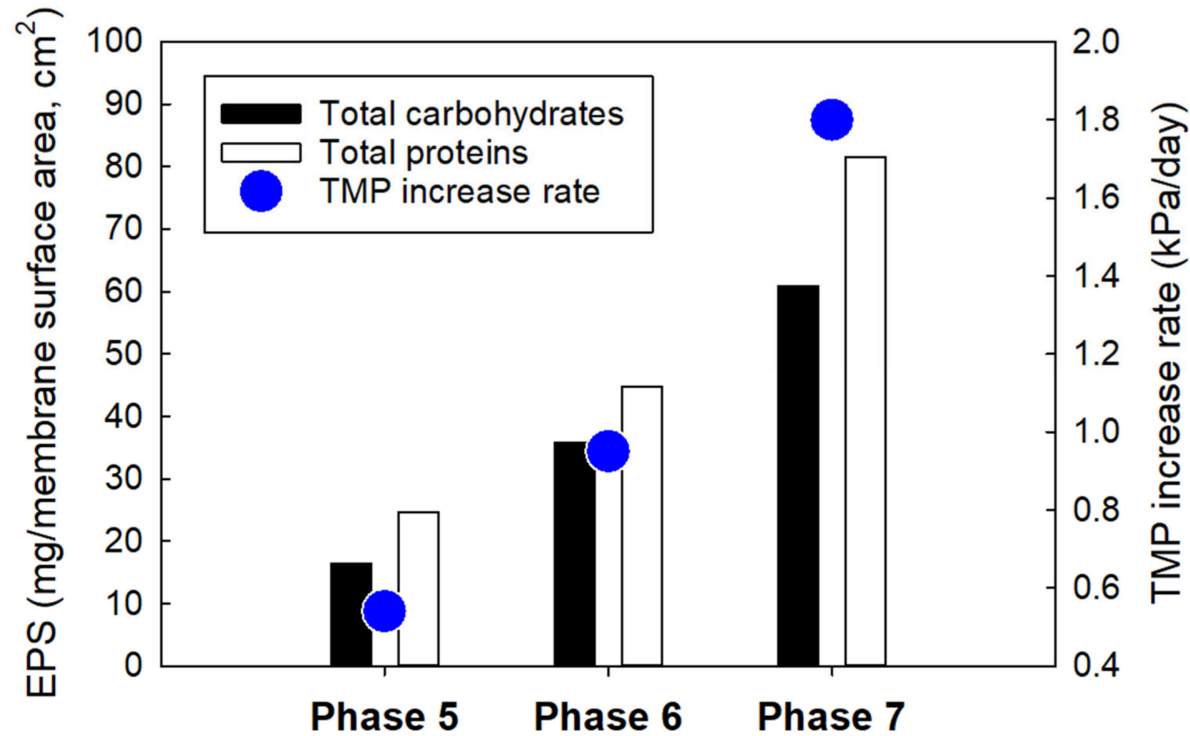

Figure 7. Correlation between EPS contents and transmembrane pressure of the PVDF membrane submerged in the anoxic or aerobic zones of the MBR as a function of time after introducing ethanol for an 8-h HRT in Phases 5-7. 


\section{Conclusions}

The anaerobic/anoxic/aerobic MBR operated with ethanol and a continuous-flow $\mathrm{MgCO}_{3}$ pellet column effectively enhanced the release and recovery of phosphorus from real municipal wastewater.

An increase in the concentration of $\mathrm{P}$ in the MBR effluent via the EBPR mechanism led to an increase in the adsorption capacity of the $\mathrm{MgCO}_{3}$ pellet column. In Phase 7, the MBR and $\mathrm{MgCO}_{3}$ system achieved a maximum $\mathrm{P}$ recovery efficiency of $91.6 \%$ and a maximum adsorption capacity of $12.8 \mathrm{mg} \mathrm{P} / \mathrm{g} \mathrm{MgCO}_{3}$. However, this operating condition was met with operational challenges due to severe membrane fouling within 15 days.

The system's overall performance was best in Phase 5 (i.e., 100\% of the MBR effluent was withdrawn from the PVDF membrane submerged in the aerobic zone) of the experiment with a removal efficiency of $>99.9 \%$ for TSS, $>99.999 \%$ for fecal coliforms, $97.8 \%$ for COD, $76.3 \%$ for $\mathrm{TN}$, and $84.6 \%$ for $\mathrm{TP}$.

This is also the ideal phase in which this system could be operated with minimal operational challenges related to membrane fouling. The $\mathrm{MBR}$ and $\mathrm{MgCO}_{3}$ system produced a high-quality effluent that was void of particles and pathogens, with low nutrient concentrations ( $<3.0 \mathrm{mg} / \mathrm{L}$ for TN and $<0.4 \mathrm{mg} / \mathrm{L}$ for TP) in the final effluent.

Ethanol, introduced as an external carbon source, effectively improved P release and denitrification efficiency in the $\mathrm{MBR}$. The $\mathrm{MgCO}_{3}$ pellets were effective in the recovery of $\mathrm{P}$ and the removal nitrogen and organic matter after the MBR.

Author Contributions: Conceptualization, Y.-H.C., M.-H.B., M.N.N. and S.C.; methodology, E.E. and H.K.; writing, E.E., Y.-H.C., M.-H.B., M.N.N., P.-K.P. and S.C.; supervision, P.-K.P. and S.C. All authors have read and agreed to the published version of the manuscript.

Funding: This research was supported by LOTTE Chemical (South Korea) and the Ohio Water Resources Center-the USGS 104(b) Grant. This study was partially funded by the Korea Ministry of Environment (MOE) and Korea Environmental Industry \& Technology Institute (KEITI) as a "Prospective green technology innovation project" [No. 2020003160019].

Institutional Review Board Statement: Not applicable.

Informed Consent Statement: Not applicable.

Acknowledgments: The authors thank Timothy Hauck for providing wastewater samples from the Muddy creek WWTP for this study.

Conflicts of Interest: The authors declare no conflict of interest.

\section{References}

1. Hao, X.; Wang, C.; van Loosdrecht, M.; Hu, Y. Looking Beyond Struvite for P-Recovery. Environ. Sci. Technol. 2013, 47, 4965-4966. [CrossRef]

2. Egle, L.; Rechberger, H.; Krampe, J.; Zessner, M. Phosphorus recovery from municipal wastewater: An integrated comparative technological, environmental and economic assessment of P recovery technologies. Sci. Total Environ. 2016, 571, 522-542. [CrossRef] [PubMed]

3. Yuan, Z.; Pratt, S.; Batstone, D. Phosphorus recovery from wastewater through microbial processes. Curr. Opin. Biotechnol. 2012, 23, 878-883. [CrossRef]

4. Kok, D.-J.D.; Pande, S.; van Lier, J.B.; Ortigara, A.R.C.; Savenije, H.; Uhlenbrook, S. Global phosphorus recovery from wastewater for agricultural reuse. Hydrol. Earth Syst. Sci. 2018, 22, 5781-5799. [CrossRef]

5. Melia, P.M.; Cundy, A.; Sohi, S.; Hooda, P.; Busquets, R. Trends in the recovery of phosphorus in bioavailable forms from wastewater. Chemosphere 2017, 186, 381-395. [CrossRef] [PubMed]

6. Qiu, G.; Song, Y.; Zeng, P.; Xiao, S.; Duan, L. Phosphorus recovery from fosfomycin pharmaceutical wastewater by wet air oxidation and phosphate crystallization. Chemosphere 2011, 84, 241-246. [CrossRef] [PubMed]

7. Song, Y.-H.; Qiu, G.-L.; Yuan, P.; Cui, X.-Y.; Peng, J.-F.; Zeng, P.; Duan, L.; Xiang, L.-C.; Qian, F. Nutrients removal and recovery from anaerobically digested swine wastewater by struvite crystallization without chemical additions. J. Hazard. Mater. 2011, 190, 140-149. [CrossRef]

8. DeSmidt, E.; Ghyselbrecht, K.; Zhang, Y.; Pinoy, L.; Van Der Bruggen, B.; Verstraete, W.; Rabaey, K.; Meesschaert, B. Global Phosphorus Scarcity and Full-Scale P-Recovery Techniques: A Review. Crit. Rev. Environ. Sci. Technol. 2014, 45, 336-384. [CrossRef] 
9. Köse, T.E.; Kıvanç, B. Adsorption of phosphate from aqueous solutions using calcined waste eggshell. Chem. Eng. J. 2011, 178, 34-39. [CrossRef]

10. Fang, C.; Zhang, T.; Li, P.; Jiang, R.-F.; Wang, Y.-C. Application of Magnesium Modified Corn Biochar for Phosphorus Removal and Recovery from Swine Wastewater. Int. J. Environ. Res. Public Health 2014, 11, 9217-9237. [CrossRef]

11. Lai, L.; Xie, Q.; Chi, L.; Gu, W.; Wu, D. Adsorption of phosphate from water by easily separable $\mathrm{Fe}_{3} \mathrm{O}_{4} @ \mathrm{SiO}_{2} \mathrm{core}$ shell magnetic nanoparticles functionalized with hydrous lanthanum oxide. J. Colloid Interface Sci. 2016, 465, 76-82. [CrossRef] [PubMed]

12. Lalley, J.; Han, C.; Li, X.; Dionysiou, D.D.; Nadagouda, M.N. Phosphate adsorption using modified iron oxide-based sorbents in lake water: Kinetics, equilibrium, and column tests. Chem. Eng. J. 2015, 284, 1386-1396. [CrossRef]

13. Freitag, F.; Kleinebudde, P. How do roll compaction/dry granulation affect the tableting behaviour of inorganic materials? Comparison of four magnesium carbonates. Eur. J. Pharm. Sci. 2003, 19, 281-289. [CrossRef]

14. Martin, E.; Lalley, J.; Wang, W.; Nadagouda, M.N.; Sahle-Demessie, E.; Chae, S.-R. Phosphate recovery from water using cellulose enhanced magnesium carbonate pellets: Kinetics, isotherms, and desorption. Chem. Eng. J. 2018, 352, 612-624. [CrossRef]

15. Oehmen, A.; Lemos, P.C.; Carvalho, G.; Yuan, Z.; Keller, J.; Blackall, L.L.; Reis, M.A. Advances in enhanced biological phosphorus removal: From micro to macro scale. Water Res. 2007, 41, 2271-2300. [CrossRef] [PubMed]

16. Morse, G.; Brett, S.; Guy, J.; Lester, J. Review: Phosphorus removal and recovery technologies. Sci. Total Environ. 1998, 212, 69-81. [CrossRef]

17. Acevedo-Juárez, B.; Oehmen, A.; Carvalho, G.; Seco, A.; Borrás, L.; Barat, R. Metabolic shift of polyphosphate-accumulating organisms with different levels of polyphosphate storage. Water Res. 2012, 46, 1889-1900. [CrossRef] [PubMed]

18. Shen, N.; Zhou, Y. Enhanced biological phosphorus removal with different carbon sources. Appl. Microbiol. Biotechnol. 2016, 100, 4735-4745. [CrossRef]

19. Wang, D.; Zheng, W.; Li, X.; Yang, Q.; Liao, D.; Zeng, G. Evaluation of the Feasibility of Alcohols Serving as External Carbon Sources for Biological Phosphorus Removal Induced by the Oxic/Extended-Idle Regime. Biotechnol. Bioeng. 2013, 110, 827-837. [CrossRef]

20. Mahoo, F. Methods for Phosphorus Recovery from Waste Water: A Review. J. Biodivers. Environ. Sci. 2018, 13, $2222-3045$.

21. Kodera, H.; Hatamoto, M.; Abe, K.; Kindaichi, T.; Ozaki, N.; Ohashi, A. Phosphate recovery as concentrated solution from treated wastewater by a PAO-enriched biofilm reactor. Water Res. 2013, 47, 2025-2032. [CrossRef] [PubMed]

22. Liao, B.Q.; Bagley, D.; Kraemer, H.E.; Leppard, G.G.; Liss, S.N. A Review of Biofouling and its Control in Membrane Separation Bioreactors. Water Environ. Res. 2004, 76, 425-436. [CrossRef]

23. Huang, J.; Shi, Y.; Zeng, G.; Gu, Y.; Chen, G.; Shi, L.; Hu, Y.; Tang, B.; Zhou, J. Acyl-homoserine lactone-based quorum sensing and quorum quenching hold promise to determine the performance of biological wastewater treatments: An overview. Chemosphere 2016, 157, 137-151. [CrossRef] [PubMed]

24. So-Ryong, C.; Yongtae, A.; Yuhoon, H.; Duksoo, J.; Fangang, M.; Jeffrey, S.; Sang-Hyup, L.; Hang-Sik, S. Membrane Biological Reactors: Theory, Modeling, Design, Management and Applications to Wastewater Reuse; IWA Publishing: London, UK, 2019.

25. Chae, S.; Murugesan, B.; Kim, H.; Duvvuru, D.K.; Lee, T.; Choi, Y.-H.; Baek, M.-H.; Nadagouda, M.N. Advanced Phosphorus Recovery from Municipal Wastewater using Anoxic/Aerobic Membrane Bioreactors and Magnesium Carbonate-Based Pellets. ACS ESET Water 2021, 1, 1657-1664. [CrossRef]

26. Nasir, A.M.; Adam, M.R.; Kamal, S.N.E.A.M.; Jaafar, J.; Othman, M.H.D.; Ismail, A.F.; Aziz, F.; Yusof, N.; Bilad, M.R.; Mohamud, R.; et al. A review of the potential of conventional and advanced membrane technology in the removal of pathogens from wastewater. Sep. Purif. Technol. 2022, 286, 120454. [CrossRef]

27. Battistoni, P.; Cola, E.; Fatone, F.; Bolzonella, D.; Eusebi, A.L. Micropollutants Removal and Operating Strategies in Ultrafiltration Membrane Systems for Municipal Wastewater Treatment: Preliminary Results. Ind. Eng. Chem. Res. 2007, 46, 6716-6723. [CrossRef]

28. Kitanou, S.; Tahri, M.; Bachiri, B.; Mahi, M.; Hafsi, M.; Taky, M.; Elmidaoui, A. Comparative study of membrane bioreactor (MBR) and activated sludge processes in the treatment of Moroccan domestic wastewater. Water Sci. Technol. 2018, 78, 1129-1136. [CrossRef]

29. Lerner, M.; Stahl, N.; Galil, N. Comparative study of MBR and activated sludge in the treatment of paper mill wastewater. Water Sci. Technol. 2007, 55, 23-29. [CrossRef] [PubMed]

30. APHA; AWWA; WEF. Standard Methods for the Examination of Water and Wastewater, 21st ed.; American Public Health Association: Washington, DC, USA, 2005.

31. Shen, Y.-X.; Xiao, K.; Liang, P.; Ma, Y.-W.; Huang, X. Improvement on the modified Lowry method against interference of divalent cations in soluble protein measurement. Appl. Microbiol. Biotechnol. 2013, 97, 4167-4178. [CrossRef]

32. Nielsen, S.S. Correction to: Food Analysis Laboratory Manual; Springer: Cham, Switzerland, 2019; pp. C1-C2. [CrossRef]

33. Felz, S.; Vermeulen, P.; van Loosdrecht, M.C.; Lin, Y.M. Chemical characterization methods for the analysis of structural extracellular polymeric substances (EPS). Water Res. 2019, 157, 201-208. [CrossRef]

34. Meng, F.; Chae, S.-R.; Drews, A.; Kraume, M.; Shin, H.-S.; Yang, F. Recent advances in membrane bioreactors (MBRs): Membrane fouling and membrane material. Water Res. 2009, 43, 1489-1512. [CrossRef] [PubMed] 
35. Meng, F.; Zhang, S.; Oh, Y.; Zhou, Z.; Shin, H.-S.; Chae, S. Fouling in membrane bioreactors: An updated review. Water Res. 2017, 114, 151-180. [CrossRef] [PubMed]

36. Chae, S.-R.; Ahn, Y.-T.; Kang, S.-T.; Shin, H.-S. Mitigated membrane fouling in a vertical submerged membrane bioreactor (VSMBR). J. Membr. Sci. 2006, 280, 572-581. [CrossRef] 